\title{
形状記憶合金を用いた適応トラスの有限要素解析*
}

都井 裕*1, 塚本和典 ${ }^{* 2}$

\section{Finite Element Analysis of Adaptive Trusses Using Shape Memory Alloys}

\author{
Yutaka TOI $^{* 1}$ and Kazunori TSUKAMOTO \\ *1 Institute of Industrial Science, University of Tokyo, \\ 4-6-1 Komaba, Meguro-ku, Tokyo. 153-8505 Japan
}

The finite element procedure for the three-dimensional adaptive trusses using shape memory alloys is formulated in the present study, in which the extended form of Brinson's constitutive equation considering the asymmetric tensile and compressive behavior is expressed in a tangentially incremental form. The validity of the present computational modeling is demonstrated by conducting numerical studies for the superelastic, shape memory behaviors of two-bar, nine-bar and twenty eight-bar adaptive trusses subjected to load and temperature changes. The proposed computational procedure is expected to be useful for the optimum design of the adaptive trusses with shape memory alloy bars.

Key Words : Finite Element Method, Adaptive Structure, Framed Structure, Shape Memory Materials, Smart Materials

\section{1. 緒言}

適応トラスとは，剛性，変形形状などの力学的特性が可変あるいは制御可能なトラス構造であり，パラボラア ンテナ, 宇宙構造物などへの適用に関心がもたれている. 外力を受けて変形した適応卜ラスは, 除荷しなくても 何らかの制御メカニズムにより元の形状を回復するなどの機能を有する. 制御メカニズムとしては，ワイヤアク チュエータを用いたもの，形状記憶合金（以下，SMA）を用いたものなどが検討されてきた ${ }^{(1),(2)}$.これらの適応卜 ラスの合理的かつ効率的な設計開発のためには，実用的な計算ツールの開発が不可欠である.

本研究は, SMA 部材を用いた適応トラスを対象とした計算ツールの構築と, 数值例によるその有用性の検証を 目的とする. SMA は, 応力と温度に依存した相変態により, 超弾性挙動, 形状記憶効果などの形状回復挙動を呈 することが知られている(3),(4). したがって，一部（または全部）の部材に SMA を用いたトラス構造は, 外力を受 けて変形しても温度上昇により元の形状に回復させるなどの制御が可能となる. 任意の応力・温度履歴下の材料 挙動を表現し得る SMA の構成方程式を, トラス構造の有限要素解析法に導入することにより, SMA 部材を用い た適応卜ラスの任意の荷重・温度条件下における応答をシミュレートすることができる.

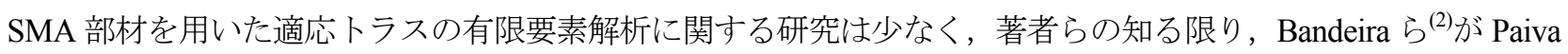
ら (3)の構成式を用いて実施した例があるだけである. しかも，初期岡性形の増分形構成式に基づいていること， 2 次元トラスのみを対象としていること, 数值例において引張挙動と圧縮挙動の非対称性が考慮されておらず, 有 限変形の影響も明示されていないことなど, 解析内容は限定されている. 本研究の有限要素解析法においては, 現象論的で簡明な Brinson の構成式(4)を引張挙動と圧縮挙動の非対称性を考慮するように拡張した上で, 数值的安 定性に優れる接線剛性形の増分形構成式を誘導し, 一般的な 3 次元トラスの増分形微小変形および有限変形解析

\footnotetext{
* 原稿受付 2011 年 1 月 16 日

*1 正員, フェロー, 東京大学生産技術研究所（广153-8505 東京都目黒区駒場 4-6-1）

*2 東京大学大学院工学系研究科

E-mail : toi@iis.u-tokyo.ac.jp
} 
に適用しており，上述の諸点の発展改良が図られている.

続く 2 章では SMA 部材を用いた適応トラスの有限要素解析法，3 章では有限要素解析例について述べる. 3 章 では, 同様の荷重・温度条件を受ける 2 次元 2 部材, 2 次元 9 部材および 3 次元 28 部材の 3 種類の適応トラスに 対する計算例により本解析法の有用性を実証しており, 2 次元 2 部材トラスでは SMA の引張・圧縮挙動の非対称 性と有限変形の影響, 2 次元 9 部材トラスでは Bandeira ら (2)による解析結果との比較, 3 次元 28 部材トラスでは変 形の 3 次元性と有限変形の影響についても言及する．最後の 4 章は結言である.

\section{2.＼cjkstart形状記憶合金部材を用いた適応トラスの有限要素解析法}

\section{$2 \cdot 1$ 形状記憶合金の構成方程式}

SMA の力学的性質を図 1 に模式的に示す．図 1(a)は応力・ひずみ曲線, 図 1(b)は变態臨界応力と温度の関係であり, 典 型的な超弾性挙動（実線矢印経路）と形状記憶効果（破線矢印経路）が示されている.

図中の $\sigma$ は応力 (第2 種ピオラ・キルヒホフ応力),$\varepsilon$ はひずみ (グリーン・ラグランジュのひずみ),$T$ は温度, $\sigma_{f}^{c r}$ と $\sigma_{s}^{c r}$ はマルテンサイト変態終了および開始臨界応力, $M_{f}$ と $M_{s}$ はマルテンサイト変態終了および開始温度, $A_{s}$ と $A_{f}$ は オーステナイト変態開始および終了温度である. 図1(b)では Brinson の定式化 ${ }^{(4)} に$ 従い， $T<M_{s}$ において $\sigma_{f}^{c r}$ と $\sigma_{s}^{c r}$ は一 定值であると仮定している. $C_{M_{s}}$ と $C_{M_{f}}$ はマルテンサイト変態開始およひ終了臨界応力と温度の関係における勾配, $C_{A_{s}}$ と $C_{A_{f}}$ はオーステナイト変態開始および終了臨界応力と温度の関係における勾配であり, 本解析では $C_{M_{s}}=C_{M_{f}}=C_{M}$ およ び $C_{A_{s}}=C_{A_{f}}=C_{A}$ と仮定している.

図 1(b)において $A_{f}$ よりも低い一定温度（ここでは $M_{f}<M_{s}<T<A_{s}<A_{f}$ ）で応力を増加し再ひ除荷すると，マルテ ンサイト変態により発生したひずみに対する逆変態 (オーステナイト変態) が完了せず，図 1(a)に示すような残留ひずみ

$\left(\varepsilon_{\text {res }}\right)$ が発生する. ここで $A_{f}$ よりも高い温度まで淕すると, 逆変態が完了し, 図1(a)に示寸ようにひずみが零となり 形状が回復する. また, 応力を除荷せずに十分加熱した場合も, 弾性ひずみは残留するが，マルテンサイト変態により発生 したひずみは消失する．これが，SMA 部材を用いた適応トラスにおいて重要な役割を果たす形状記憶効果の概略である. また $T>A_{f}$ の場合は, 逆変態が完了するため, 超弾性挙動が発現する.

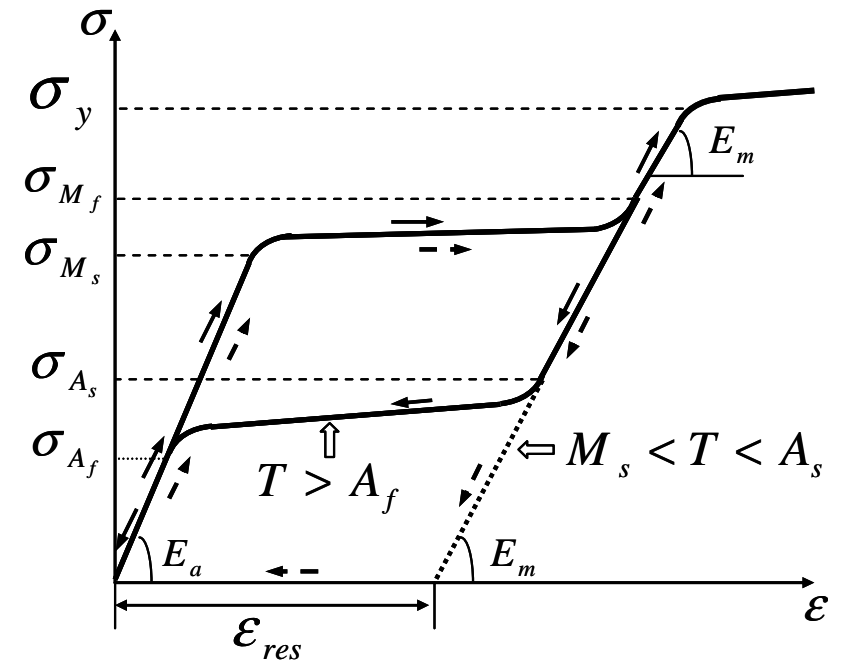

(a) Superelastic behavior and shape memory effect

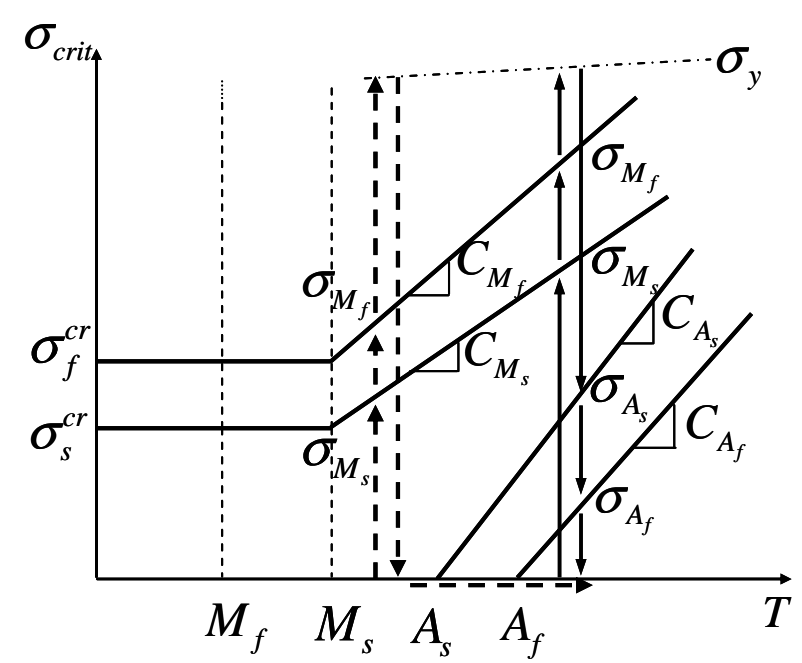

(b) Critical stresses for transformation vs. temperature

Fig.1 Mechanical properties of shape memory alloys

SMA の 1 次元応力・ひずみ関係は一般に，次式のように書ける(4).

$$
\sigma-\sigma_{0}=E(\xi) \varepsilon-E\left(\xi_{0}\right) \varepsilon_{0}+\Omega(\xi) \xi_{S}-\Omega\left(\xi_{0}\right) \xi_{S 0}+\theta\left(T-T_{0}\right)
$$

ここに, $E$; ヤング率, $\Omega$; 変態係数, $\xi$; マルテンサイト相体積率, $\xi_{S}$; 応力誘起マルテンサイト相体積率, $\theta$; 熱弾性係数， $T$; 温度である. 下添字 “0” は初期值を意味する. 
$\Omega$ は, 次式のように表現される.

$$
\Omega=-\varepsilon_{\text {res }} E
$$

ここに， $\varepsilon_{\text {res }}$ は最大残留ひずみである.

ヤング率 $E$ は, マルテンサイト相体積率 $\xi$ の関数であり, 次式で与えられる.

$$
E=E_{a}+\xi\left(E_{m}-E_{a}\right)
$$

ここに， $E_{m}$ および $E_{a}$ はそれぞれ，マルテンサイト相およびオーステナイト相のヤング率である.

マルテンサイト相体積率 $\xi$ は, 次式のように表現される.

$$
\xi=\xi_{S}+\xi_{T}
$$

ここに， $\xi_{T}$ は温度誘起マルテンサイト相体積率である. $\xi_{S}$ および $\xi_{T}$ は，応力 $\sigma$ と温度 $T$ の関数である ${ }^{(4)}$. 温 度誘起マルテンサイト相は純粋な温度変化 $\left(M_{f} \leq T \leq M_{s}, \sigma \leq \sigma_{s}^{c r}\right)$ により誘起される双晶（twinned）マル テンサイト相であり, 前述の応力誘起マルテンサイト相は非双晶 (detwinned) マルテンサイト相である. 両者の 力学的挙動に与える影響は厳密には異なるはずであるが, 本研究では Brinson ${ }^{(4)} に$ 従って式(3), 式(4)に示すように, 両者は加算的に作用寸ると仮定している. また， 3 章の例題には温度誘起マルテンサイト変態過程は含まれない が，一般的な適応卜ラス設計においてはこれを考慮する必要があるため，定式化には含めている.

SMA におけるマルテンサイト変態の圧力依存性 ${ }^{(5)(6)}$ に起因して生ずる引張挙動と圧縮挙動の非対称性を考慮す

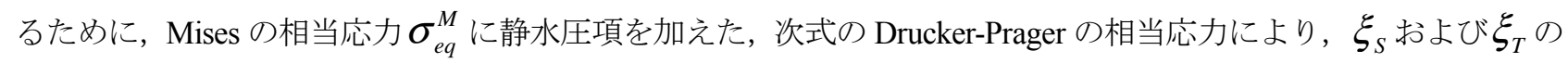
発展方程式を記述する.

$$
\sigma_{e q}^{D P}=\sigma_{e q}^{M}+3 \beta \sigma_{H}
$$

ここに， $\beta$ は材料パラメータであり， $\sigma_{H}$ は次式で与えられる静水圧である.

$$
\sigma_{H}=\frac{1}{3}\left(\sigma_{x}+\sigma_{y}+\sigma_{z}\right)
$$

一次元の場合, 式(5)の相当応力は,

$$
\sigma_{e q}^{D P}=\beta \sigma+|\sigma|
$$

と表現される. なお，最大残留ひずみを始めとするいくつかの材料定数が引張挙動と圧縮挙動で異なる值をとる 可能性があるが，対象とする SMA 部材の引張および圧縮両挙動に関する精細な材料試験結果が与えられれば, 本定式化はそのような場合にも容易に拡張適用することが可能である.ただし，3 章の例題計算では表 1 に示寸 同じ值を仮定している.

Brinson $^{(4)}$ により与えられた $\xi_{S}$ および $\xi_{T}$ の発展方程式に式(7)を代入すると，マルテンサイト相あるいはオース テナイト相への変態に対し, 次式のような形の発展方程式が得られる. 具体形は複雑なため省略する.

$$
\begin{aligned}
& \xi_{S}=\xi_{S}\left(\sigma_{e q}^{D P}, T\right) \\
& \xi_{T}=\xi_{T}\left(\sigma_{e q}^{D P}, T\right)
\end{aligned}
$$

式(1)において与えられた応力・ひずみ関係式は，微分形で次のように表わせる.

$$
\begin{aligned}
d \sigma= & d E \mathcal{E}+E d \varepsilon+d \Omega \xi_{s}+\Omega d \xi_{s}+d \theta T+\theta d T \\
= & \frac{d E}{d \xi}\left(\frac{\partial \xi}{\partial \sigma} d \sigma+\frac{\partial \xi}{\partial T} d T\right) \mathcal{E}+E d \varepsilon+\frac{d \Omega}{d E} \frac{d E}{d \xi}\left(\frac{\partial \xi}{\partial \sigma} d \sigma+\frac{\partial \xi}{\partial T} d T\right) \xi_{s} \\
& +\Omega\left(\frac{\partial \xi_{s}}{\partial \sigma} d \sigma+\frac{\partial \xi_{s}}{\partial T} d T\right)+\frac{d \theta}{d E} \frac{d E}{d \xi}\left(\frac{\partial \xi}{\partial \sigma} d \sigma+\frac{\partial \xi}{\partial T} d T\right) T+\theta d T
\end{aligned}
$$


増分形の応力・ひずみ関係は，以下のように求められる.

$$
\begin{aligned}
& {\left[1-\frac{d E}{d \xi} \frac{\partial \xi}{\partial \sigma} \varepsilon-\frac{d \Omega}{d E} \frac{d E}{d \xi} \frac{\partial \xi}{\partial \sigma} \xi_{s}-\Omega \frac{\partial \xi_{s}}{\partial \sigma}-\frac{d \theta}{d E} \frac{d E}{d \xi} \frac{\partial \xi}{\partial \sigma} T\right] d \sigma } \\
= & E d \varepsilon+\left[\frac{d E}{d \xi} \frac{\partial \xi}{\partial T} \varepsilon+\frac{d \Omega}{d E} \frac{d E}{d \xi} \frac{\partial \xi}{\partial T} \xi_{s}+\Omega \frac{\partial \xi_{s}}{\partial T}+\frac{d \theta}{d E} \frac{d E}{d \xi} \frac{\partial \xi}{\partial T} T+\theta\right] d T
\end{aligned}
$$

よって, 有限要素解析のための増分形の応力・ひずみ関係式は, 次のような形に書ける.

$$
\Delta \sigma=D_{S E}\left\{\Delta \varepsilon-\Delta \varepsilon_{S M}(\Delta T)\right\}
$$

ここに,

$$
\begin{aligned}
D_{S E} & =\frac{E}{1-\frac{d E}{d \xi} \frac{\partial \xi}{\partial \sigma} \varepsilon-\frac{d \Omega}{d E} \frac{d E}{d \xi} \frac{\partial \xi}{\partial \sigma} \xi_{S}-\Omega \frac{\partial \xi_{S}}{\partial \sigma}-\frac{d \theta}{d E} \frac{d E}{d \xi} \frac{\partial \xi}{\partial \sigma} T} \\
\Delta \varepsilon_{S M}(\Delta T) & =-\frac{\left[\frac{d E}{d \xi} \frac{\partial \xi}{\partial T} \varepsilon+\frac{d \Omega}{d E} \frac{d E}{d \xi} \frac{\partial \xi}{\partial T} \xi_{S}+\Omega \frac{\partial \xi_{S}}{\partial T}+\frac{d \theta}{d E} \frac{d E}{d \xi} \frac{\partial \xi}{\partial T} T+\theta\right] d T}{E}
\end{aligned}
$$

式(12a)の $D_{S E}$ は接線剛性係数, 式(12b)の $\Delta \varepsilon_{S M}(\Delta T)$ は温度増分に依存する初期ひずみ増分（固有ひずみ増分） である. 他方, Bandeira ら ${ }^{(2)}$ が適応卜ラスの解析に用いた SMA の構成式は, 以下のような初期剛性形である.

$$
\Delta \sigma=E \Delta \varepsilon+\Delta \sigma_{i}
$$

式(11)と式(13)の剛性係数（ひずみ増分の係数）の違いに着目されたい. 接線剛性係数を採用した式(11)の方が計 算効率，精度に優れている(7).

\section{$2 \cdot 2$ 適応トラスの有限要素解析法}

ラグランジュ法(7)に基づいて, 有限変形の仮定のもとで形状記憶合金を用いた適応卜ラス要素の増分形有限要 素解析法の定式化を行う。

図 2 を参照して, 3 次元トラス要素内の変位場を次式のように仮定する.

$$
\begin{aligned}
& u(z)=\left(1-\frac{z}{l}\right) u_{i}+\frac{z}{l} u_{j} \\
& v(z)=\left(1-\frac{z}{l}\right) v_{i}+\frac{z}{l} v_{j} \\
& w(z)=\left(1-\frac{z}{l}\right) w_{i}+\frac{z}{l} w_{j}
\end{aligned}
$$

ここに, $u(z)$ と $v(z)$ は横変位, $w(z)$ は軸方向変位, $u_{i}, v_{i}, w_{i}$ などは節点変位，l㴗素長である.

増分形のひずみ・変位関係式を次式のように仮定する.

$$
\Delta \varepsilon=\frac{d \Delta w}{d z}+\frac{d u}{d z} \frac{d \Delta u}{d z}+\frac{d v}{d z} \frac{d \Delta v}{d z}+\frac{1}{2}\left[\left(\frac{d \Delta u}{d z}\right)^{2}+\left(\frac{d \Delta v}{d z}\right)^{2}\right]
$$

式(15)においては，横変位に関する非線形項のみを考慮し，それらの項と比べ一般に絶対值の小さい軸方向変位 に関する非線形項は無視している.

よって，ひずみ増分の線形成分と節点変位増分の関係式は，マトリックス形で以下のように表現される. 


$$
\Delta \varepsilon=[\bar{B}]\{\Delta d\}=\left(\left[B_{0}\right]+\left[B_{L}\right]\right)\{\Delta d\}
$$

ここで次のような記号を用いている. $[\bar{B}]$; ひずみ・節点変位マトリックス， $\left[B_{0}\right]$; 初期変位の影響を除いた ひずみ・節点変位マトリックス, $\left[B_{L}\right]$; 初期変位の影響を含むひずみ・節点変位マトリックス, $\{\Delta d\}$; 節点変 位増分ベクトル $\left(\lfloor d\rfloor=\left\lfloor u_{i} v_{i} w_{i} u_{j} v_{j} w_{j}\right\rfloor\right)$.

2.1 節で誘導した SMA の増分形構成式 (式(11)）に基づいて, 仮想仕事の原理による有限要素定式化を行うと, 次式のような SMA 部材の增分形要素剛性方程式を得る.

$$
\left(\left[k_{0}\right]+\left[k_{L}\right]+\left[k_{G}\right]\right)\{\Delta d\}=\{\Delta f\}+\left\{\Delta f_{S M}\right\}+\left\{f_{R}\right\}
$$

ここに,

$$
\begin{gathered}
{\left[k_{0}\right]=\int_{V^{e}}\left[B_{0}\right]^{T} D_{S E}\left[B_{0}\right] d V^{(0)}} \\
{\left[k_{L}\right]=\int_{V^{V}}\left(\left[B_{0}\right]^{T} D_{S E}\left[B_{L}\right]+\left[B_{L}\right]^{T} D_{S E}\left[B_{0}\right]+\left[B_{L}\right]^{T} D_{S E}\left[B_{L}\right]\right) d V^{(0)}} \\
{\left[k_{G}\right]=\int_{V^{e}}[G]^{T}[S][G] d V^{(0)}} \\
\left\{\Delta f_{S M}\right\}=\int_{V^{e}}[\bar{B}]^{T} D_{S E} \Delta \varepsilon_{S M}(\Delta T) d V^{(0)}
\end{gathered}
$$

式中, 以下の記号を用いている. $\left[k_{0}\right]$; 増分剛性マトリックス, $\left[k_{L}\right]$; 初期変位マトリックス, $\left[k_{G}\right]$; 初期応 カマトリックス, $\{\Delta f\}$; 外力増分ベクトル, $\left\{\Delta f_{S M}\right\} ; \Delta \varepsilon_{S M}(\Delta T)$ に依存する見かけの外力増分, $\left\{f_{R}\right\} ;$ 不平 衡カベクトル， $D_{S E} ;$ 式(11)の接線剛性係数, $\Delta \varepsilon_{S M}(\Delta T)$; 式(11)の温度増分に依存する初期ひずみ, $[G]$; 勾 配マトリックス, $[S]$; 応カマトリックス, $V^{e}$; 要素体積. なお, SMA 部材以外の鋼製部材に対する増分形要 素剛性方程式は自明であるので省略する。

以上の定式化により，SMA 部材を用いた一般的な 3 次元適応トラスに対し，任意の荷重・温度条件下の超弾性 挙動，形状記憶効果をシミュレート寸ることが可能である．たとえば，３章の数值例においては，以下のような 計算が行われている. まず一定温度条件下で, SMA 部材を用いたトラス構造に外力を負荷する. この際のマルテ ンサイト変態・変形解析においては, 式(17)の $\left\{\Delta f_{S M}\right\}=\{0\}$ であり, 外力増分 $\{\Delta f\}$ のみが負荷される. 続いて 一定外力を載荷したまま, 変形したトラス構造に温度上昇および温度下降を負荷する。この際のオーステナイト 変態・変形回復, マルテンサイト変態・再変形解析に损いては, 式(17)の $\{\Delta f\}=\{0\}$ であり, 温度変化に依存す る見かけの外力増分 $\left\{\Delta f_{S M}\right\}$ のみが負荷される。このように SMA 部材に対する式(11)の増分形構成式と式(17)の 增分形要素剛性方程式を利用することにより, SMA 部材を用いた適応卜ラスの任意の荷重・温度条件下における 応答計算を行うことができるため, SMA 部材の寸法, 配置, 材料特性などに関する設計の最適化が可能となる.

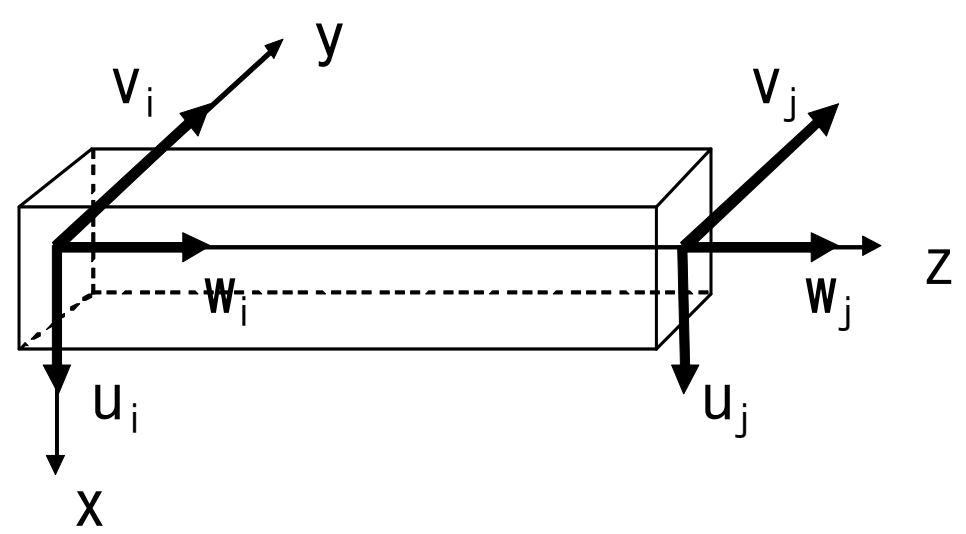

Fig.2 Three-dimensional truss element, local coordinates and nodal displacements 


\section{3. 形状記憶合金部材を用いた適応トラスの有限要素解析例}

1 章, 2 章で述べたように, 本研究で提案した適応トラスの有限要素解析法の特長, すなわち既存の手法に対す る卓越点は, (1)実験的に存在が確認されている SMA の引張挙動と圧縮挙動の非対称性 ${ }^{(5)}$ を考慮していること, (2) 計算精度, 効率に優れる接線剛性形の増分形構成式を誘導していること, (3)一般的な 3 次元卜ラスの増分形微小 変形および有限変形解析に適用可能であること，の 3 点である.これらはいずれも SMA 部材を用いた適応卜ラ スの汎用計算ツールとして求められる機能であることは明らかである. 本章では, 本解析法の妥当性と有用性を 実証するために，SMA 部材を用いた数例の適応トラスに対寸る数值計算を行う.ただし，SMA 部材を用いた適 応卜ラスは構想段階の構造物であることから, 比較対象とすることが可能な実験結果は皆無であり, 計算結果と しても引張・圧縮挙動の非対称性を含めない Bandeira の解析結果 ${ }^{(2)}$ があるのみである. したがって, 主として本 解析結果自体の定性的考察により本解析手法が妥当な適応卜ラス解を与えることを確認しており, Bandeira の解 析結果との比較も $\beta=0$ の条件下で行われていることを付言しておく.

\section{$3 \cdot 1$ 形状記憶合金の材料定数の同定}

Ni-Ti SMA に対する Tobushi $ら^{(8)}$ の実験結果を参照して, 2.1 節に示した SMA の材料定数を, 表 1 のように決定 した. 式(7)の $\beta$ については, 解析例により $\beta=0.15$ または $\beta=0$ を用いている. $\beta=0.15$ は, Ni-Ti-10\%Cu SMA

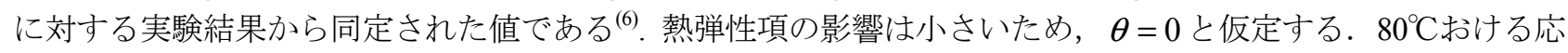
力・ひずみ曲線の同定結果を Tobushi $ら^{\left({ }^{(8)}\right.}$ の実験結果と比較して図 3 に示寸. 両者は良好に対応している. なお表 中, $E_{s}$ は鋼材のヤング率であり, 鋼製部材は線形弾性体と仮定している.

Table 1.Material constants identified for SMA test result by Tobushi et al. ${ }^{(8)}$

\begin{tabular}{|c|c|}
\hline \multirow{4}{*}{ Elastic modulus } & $E_{a}=54 \mathrm{GPa}$ \\
\cline { 2 - 2 } Transformation temperatures & $E_{m}=42 \mathrm{GPa}$ \\
\cline { 2 - 2 } & $E_{s}=200 \mathrm{GPa}$ \\
\cline { 2 - 2 } & $M_{f}=10{ }^{\circ} \mathrm{C}$ \\
\cline { 2 - 2 } & $M_{s}=20{ }^{\circ} \mathrm{C}$ \\
\cline { 2 - 2 } Transformation constants & $A_{s}=46.25{ }^{\circ} \mathrm{C}$ \\
\hline \multirow{5}{*}{} & $A_{f}=56.25{ }^{\circ} \mathrm{C}$ \\
\cline { 2 - 2 } & $C_{M}=9.25 \mathrm{MPa} /{ }^{\circ} \mathrm{C}$ \\
\cline { 2 - 2 } & $C_{A}=8.0 \mathrm{MPa} /{ }^{\circ} \mathrm{C}$ \\
\cline { 2 - 2 } & $\sigma_{s}^{c r}=50 \mathrm{MPa}$ \\
\hline Maximum residual strain & $\sigma_{f}^{c r}=150 \mathrm{MPa}$ \\
\hline
\end{tabular}

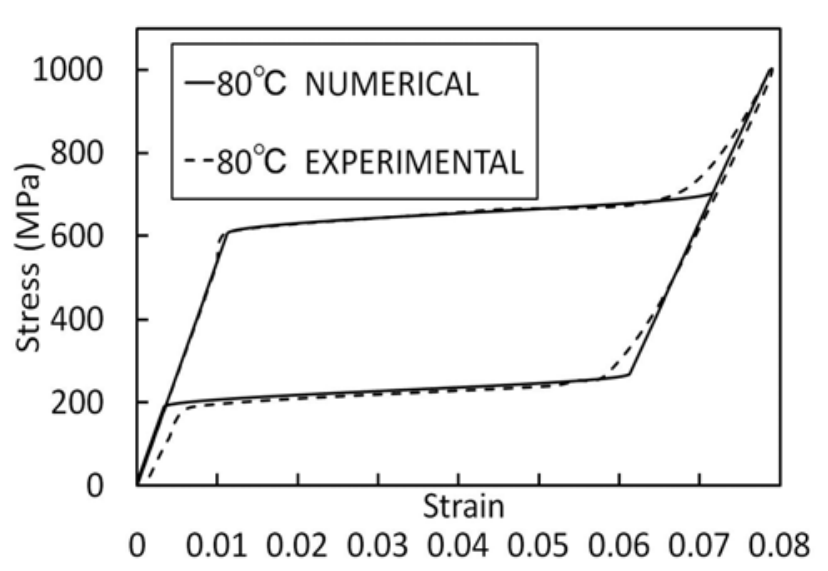

Fig. 3 Experimental and identified stress-strain curves for SMA at $80^{\circ} \mathrm{C}$ 


\section{$3 \cdot 22$ 次元 2 部材適応トラス}

3.1 節で同定した材料定数を用いて, 図 4 に示寸 2 次元 2 部材の適応トラスを図中の荷重・温度条件の下で解析 した. 部材(1)および(2)はともに SMA であり,断面積は $1 \mathrm{~cm}^{2}$ である. 荷重 $F(t)$ は $t=0 \sim 1.0$ で増加し, $t=1.0 \sim 3.0$ で一定値を保つ. 温度は $t=0 \sim 1.0$ で $M_{f}$ 以下の一定值を保ち, $t=1.0 \sim 2.0$ で $A_{f}$ 以上に上昇し, $t=2.0 \sim 3.0$ で 元に戻る. なお本解析例では, 式(7)において $\beta=0.15$ と仮定し, SMA の引張挙動と圧縮挙動の非対称性を考慮 するとともに, 微小変形解析結果と有限変形解析結果を比較する.

図 5 は, 荷重点における鉛直下方変位の時刻歴である. $t=0 \sim 1.0$ では荷重増加に伴い, SMA 部材のマルテン サイト変態による $30 \mathrm{~mm}$ 程度の変位が発生している. $t=1.0 \sim 2.0$ では, 温度上昇に伴うオーステナイト変態に より, マルテンサイト変態による変位が消失し, 弾性変形分のみが残留している. $t=2.0 \sim 3.0$ では温度下降に 伴い, 再びマルテンサイト変態が起こり, $30 \mathrm{~mm}$ 程度の変位が発生している. なお, 変位の絶対值が部材長の $10 \%$ 程度とあまり大きくないため, 図 5 においては微小変形解析結果と有限変形解析結果に大きな相違は見られない.

図 6 は各部材の応力・ひずみ曲線である. 部材(1)には引張応力が発生し, 部材(2)には圧縮応力が発生する. 両 部材とも, $t=0 \sim 1.0$ における荷重増加によりマルテンサイト変態が終了して応力ピーク值に到達, $t=1.0 \sim 2.0$ の温度上昇に伴うオーステナイト変態によりひずみがほぼ消失, $t=2.0 \sim 3.0$ の温度下降に伴う再マルテンサイ 卜変態により再びひずみが発生という経過をたどる. 微小変形解析においては, 部材1)（引張側）と部材(2)（圧 縮側）のピーク応力は完全に対称的であるが，有限変形影響は正の応力変動をもたらすため，有限変形解析にお いては, 部材(1)と部材(2)のピーク応力は非対称的となっている. また， $\beta=0.15$ を仮定したため, マルテンサイ 卜変態開始および終了限界応力の絶対值は, 部材(2) (圧縮側) の方が部材 (1)（引張側）よりも $30 \%$ 程度高くなっ ている. 以上の解析結果より, 2 次元適応トラスに対し本解析法は合理的な解を与えていると判断される.
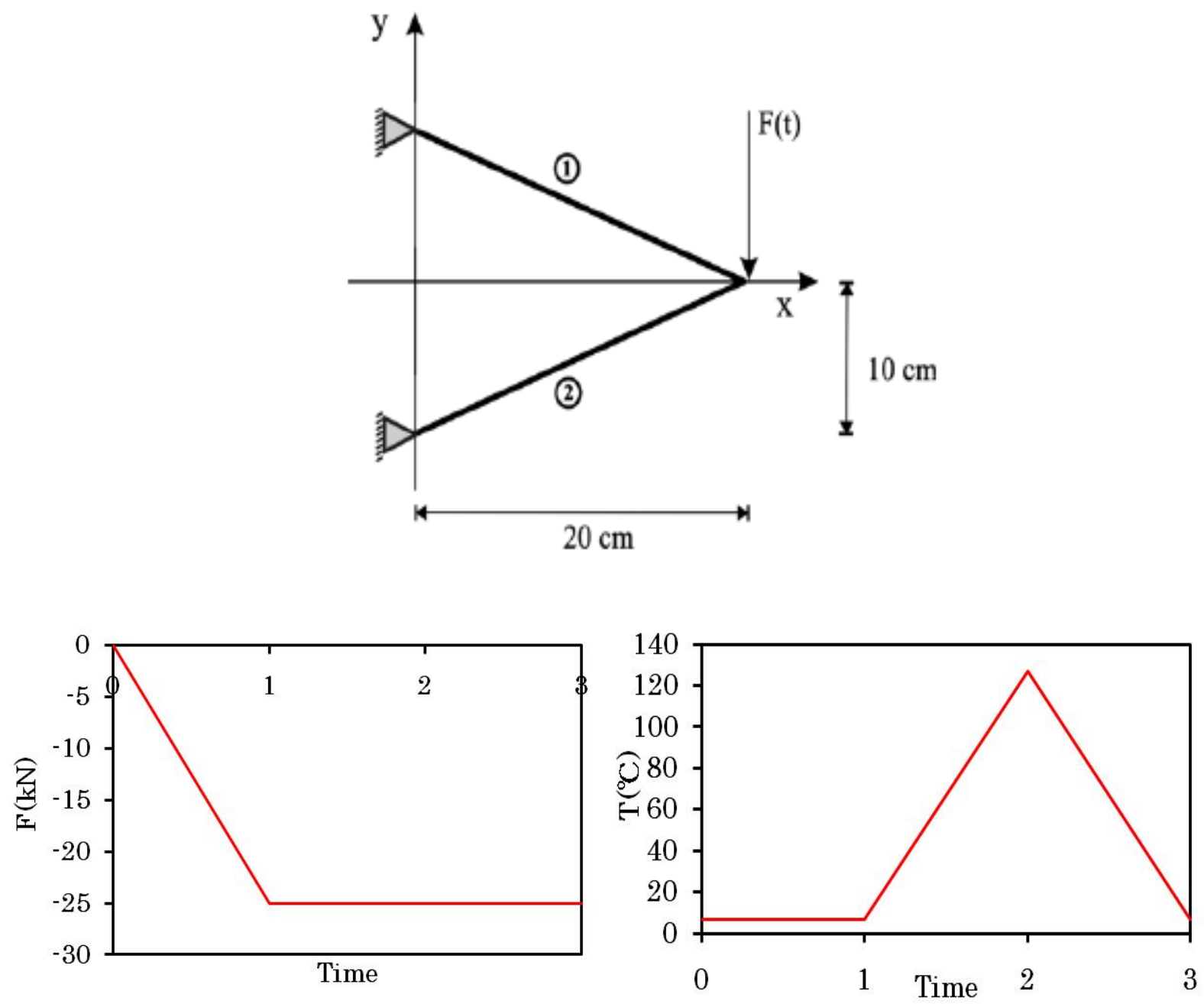

Fig.4 Two-bar truss and load/temperature condition 

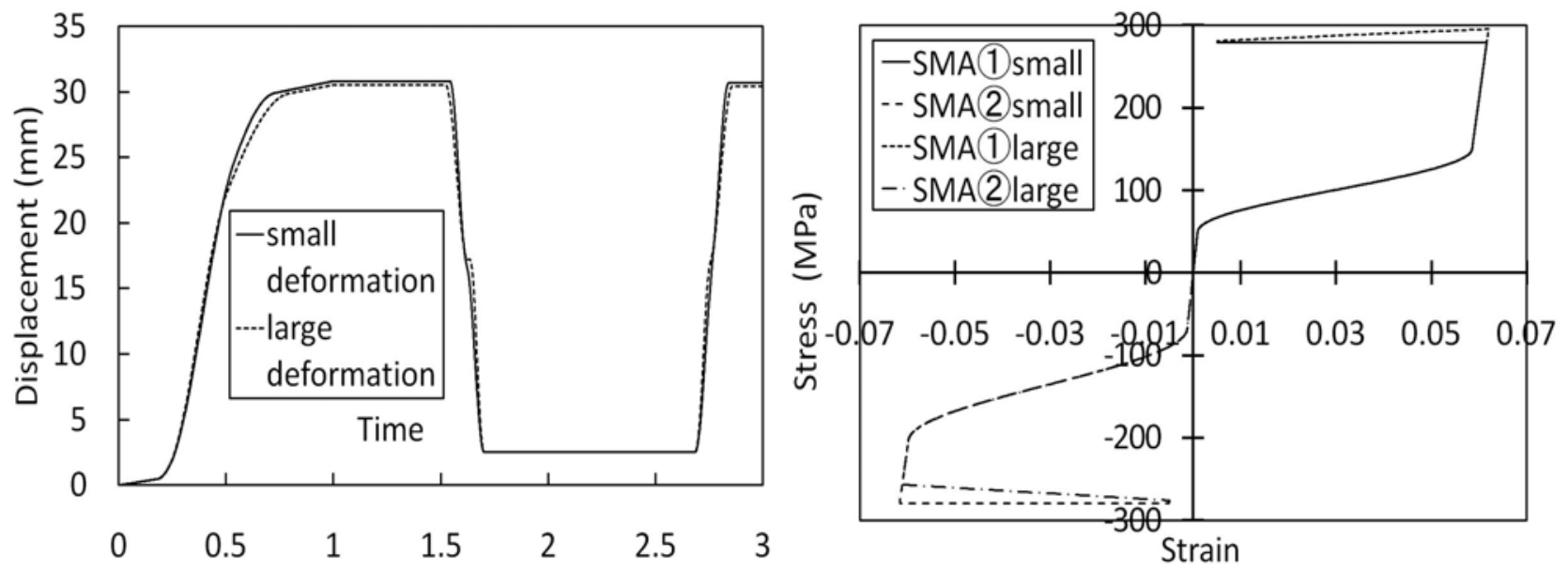

Fig.5 Time-history of displacement at loaded point of two-bar truss Fig.6 Stress-strain curve for SMA members of two-bar truss

\section{$3 \cdot 32$ 次元 9 部材適応トラス}

3.1 節で同定した材料定数を用いて, 図 7 に示寸 2 次元 9 部材の適応トラスを解析した. ブレース部材(3)と(5) SMA，他の部材は鋼であり，断面積はいずれも $1 \mathrm{~cm}^{2}$ である. 荷重条件, 温度条件は図 4 と同様である. すなわち, 荷重 $F(t)$ は $t=0 \sim 1.0$ で増加し, $t=1.0 \sim 3.0$ で一定值を保つ. 温度は $t=0 \sim 1.0$ で $M_{f}$ 以下の一定值を保ち, $t=1.0 \sim 2.0$ で $A_{f}$ 以上に上昇し, $t=2.0 \sim 3.0$ で元に戻る. なお本解析例では, Bandeira ${ }^{(2)}$ の解析結果と比較す るため, 式(7)において $\beta=0$ とし, SMAの引張挙動と圧縮挙動の対称性を仮定する.

図 8 は, 荷重点における鉛直下方変位の時刻歴である. 2 部材トラスに対する図 5 の解析結果と同様に, 変形・ 回復・再変形過程が良好にシミュレートされている. 寸なわち, $t=0 \sim 1.0$ では荷重増加に伴い, SMA 部材のマ ルテンサイト変態による $25 \mathrm{~mm}$ 程度の変位が発生している. $t=1.0 \sim 2.0$ では, 温度上昇に伴うオーステナイト 変態により, マルテンサイト変態による恋位が消失し, 弾性変形分のみが残留している. $t=2.0 \sim 3.0$ では温度 下降に伴い，再びマルテンサイト変態が起こり，25mm 程度の変位が発生している．Paiva $ら^{(3)}$ の構成式を用いた Bandeira $ら^{(2)}$ の解析結果と比較すると, SMA 構成式の違いにより変形の進行・回復過程における勾配には若干 の相違があるが, 変位の極大值と極小值は数\%以内の差で一致しており, 本解析法の定量的妥当性が確認される.

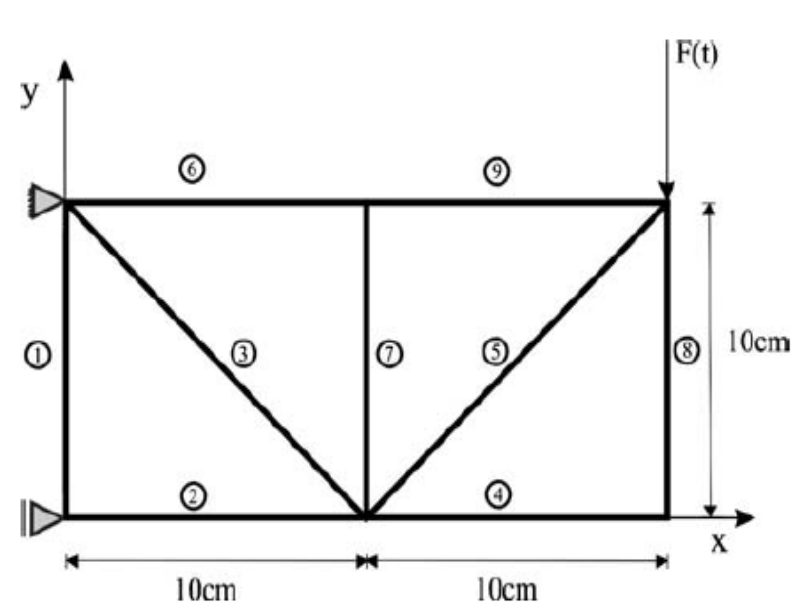

Fig.7 Nine-bar truss

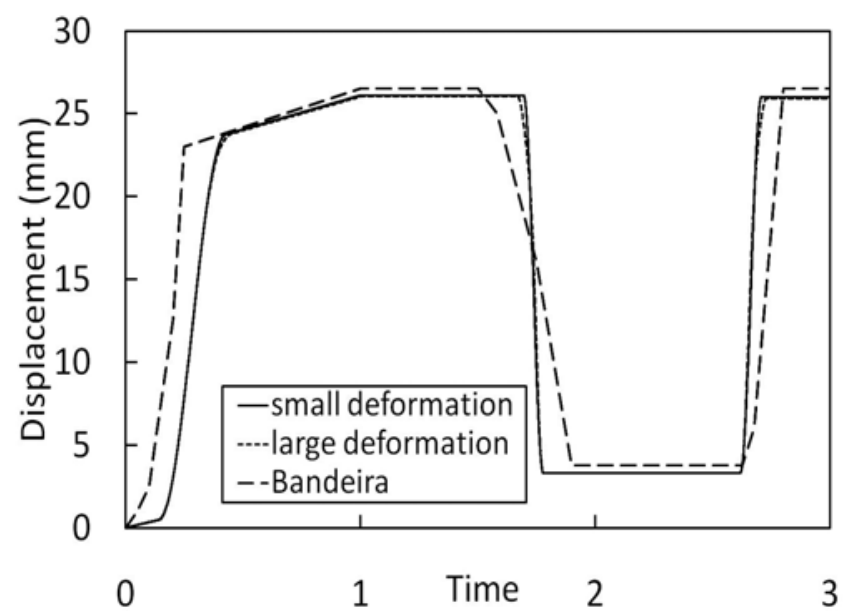

Fig.8 Time-history of displacement at loaded point of nine-bar truss

\section{$3 \cdot 43$ 次元 28 部材適応トラス}

3.1 節で同定した材料定数を用いて, 図 9 に示寸 3 次元 28 部材の適応トラスを解析した. 本トラスの左右の側 面は, 図 7 の 2 次元 9 部材トラスと同様であり，上下面の部材でそれらを結合している. 左側面のブレース部材

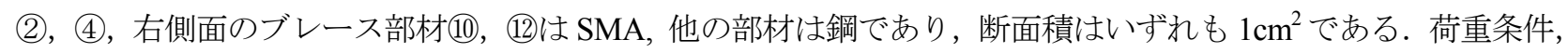


温度条件は図 4 と同様である. なお本解析例でも, 式(7)において $\beta=0$ とし, 変形の 3 次元性および有限変形の 影響に着目する.

図 9 の荷重点 $\mathrm{A}$ および隣接点 $\mathrm{B}$ における鉛直下方変位の時刻歴を図 10 に示寸. 荷重点 $\mathrm{A}$ における変位 (WA) の時刻歴は, 図 5 の 2 次元 2 部材トラス, 図 8 の 2 次元 9 部材卜ラスの解析結果と定性的に同様であり, 適応卜 ラスとしての特性が理解される．微小変形解析では点 B における変位（WB） は発生しないが，有限変形解析で

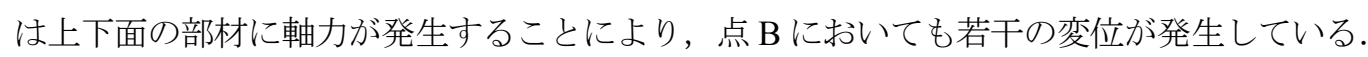

図 11 は，有限変形解析による SMA 部材(2)，(4)，(10および(12)の応力の時刻歴である，SMA 部材(2)，(4)の応力 絶対值に着目すると. $t=0 \sim 1.0$ では荷重負荷により増大し, $t=1.0 \sim 2.0$ では変形回復時の有限変形影響により 若干増大, $t=2.0 \sim 3.0$ では再変形時の有限変形影響により若干減少している. 部材10および12には有限変形の

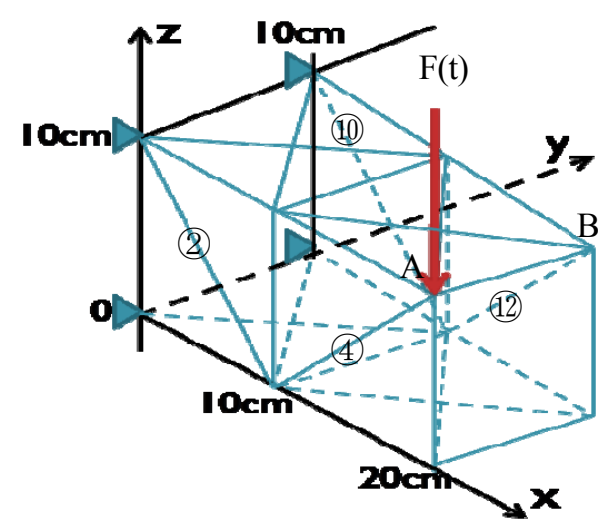

Fig.9 Twenty eight-bar truss

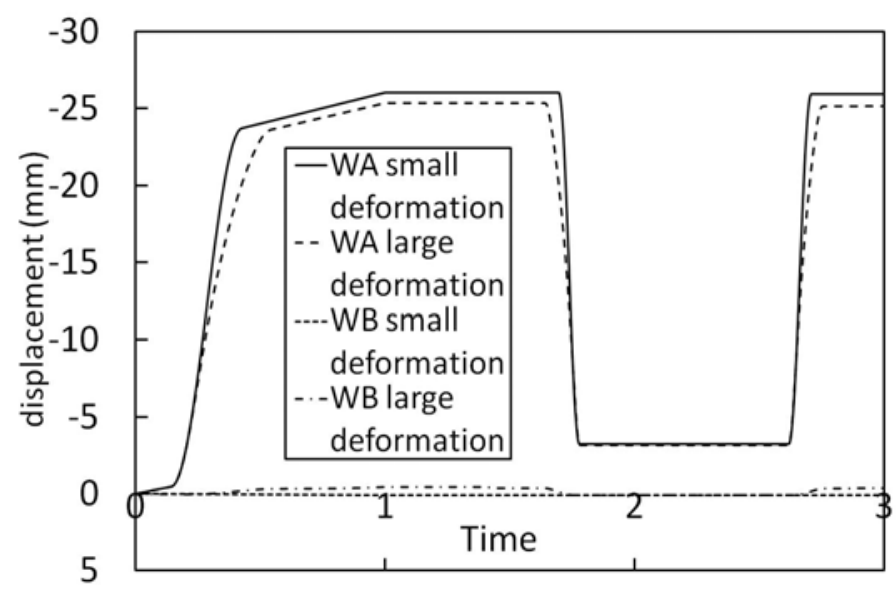

Fig.10 Time-history of displacement at A and B of twenty eight-bar truss

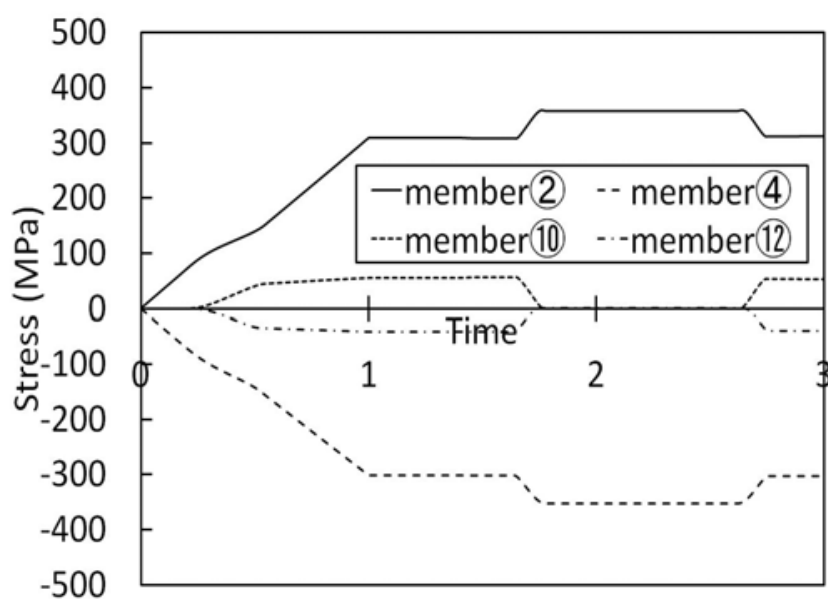

Fig.11 Time-history of stress for SMA members of twenty eight-bar truss

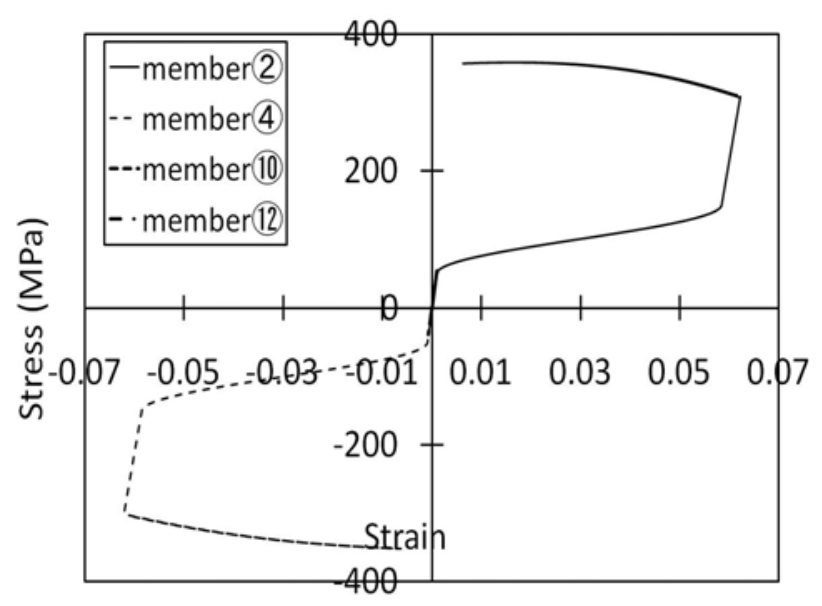

Fig.12 Stress-strain curve for SMA members of twenty eight-bar truss

影響による小さい応力が発生している. 図 12 は同じくSMA 部材(2), (4), (10および12の応力・ひずみ曲線である. SMA 部材(2), (4)の応力・ひずみ曲線は, 図 11 の応力時刻歴と対応している. 部材(10) と(12)応力・ひずみ曲線は 最大応力值が $50 \mathrm{MPa}$ 程度であり, それぞれ部材(2)と(4)の応力・ひずみ曲線の弾性変形部と重なっている. 以上の 解析結果より，3 次元適応卜ラスに対し本解析法は妥当な解を与えていると判断される.

\section{4. 結語}

本研究では, 形状記憶合金に対する Brinsonの構成式において引張挙動と圧縮挙動の非対称性を考慮した上で, 接線剛性形の増分形構成式を誘導し，一部に形状記憶合金部材を用いた 3 次元適応卜ラスを対象とする有限変形 下の増分形有限要素解析法を定式化した。 
その定式化を，形状記憶合金部材を用いた 2 次元 2 部材, 2 次元 9 部材および 3 次元 28 部材の適応トラスが荷 重を受けてマルテンサイト変態により変形し, 続く温度上昇・下降時のオーステナイト・マルテンサイト変態に より変形回復・再変形する過程の解析に適用し，他の数值解との比較および引張・圧縮非対称性，有限変形など の影響に関する定性的考察により，計算アルゴリズムの妥当性と有用性を確認した.

本有限要素解析は, 形状記憶合金部材を用いた一般的な 3 次元適応トラスに対する解析として初めての試みで ある．本計算手法を用いることにより，任意の荷重・温度条件下の超弾性挙動，形状記憶効果をシミュレートす ることが可能であり，形状記憶合金部材を用いた適応卜ラスの合理的かつ効率的な設計開発に貢献することが期 待される.

文献

（1）花原和之，多田幸生，”ワイヤをアクチュエータとする不静定適応トラス（動特性を考慮した構造設計）”，日本機 械学会（No.03-7） Dynamics and Design Conference CD-ROM 論文集， (2003).

(2) Bandeira, E. L., Savi, M. A., Camara Monteiro Jr., P. C. and Netto, T. A, "Finite Element Analysis of Shape Memory Alloy Adaptive Trusses with Geometrical Nonlinearities", Archive of Applied Mechanics, Vol.76 (2006), pp.133-144.

(3) Paiva, A., Savi, M. A., Braga, A. M. B. and Pacheco, P. M. C. L., "A Constitutive Model for Shape Memory Alloys Considering Tensile-Compressive Asymmetry and Plasticity”, International Journal of Solids and Structures, Vol.42, No.11-12 (2005), pp.3439-3457.

(4) Brinson, L. C., "One-Dimensional Constitutive Behavior of Shape Memory Alloys: Thermomechanical Derivation with Non-Constant Material Functions and Redefined Martensite Internal Variable", Journal of Intelligent Material Systems and Structures, Vol 4, No.2 (1993), pp.229-242.

(5) Kakeshita, T., Shimizu, K., Nakamichi, S., Tanaka, R., Endo, S. and Ono, F., "Effect of Hydrostatic Pressures on Thermoelasticmartensitic Transformations in Aged Ti-Ni and Ausaged Fe-Ni-Co-Ti Shape Memory Alloys", Materials Transactions (The Japan Institute of Metals), 33 (1992), pp.1-6.

(6) Auricchio, F. and Taylor, R. L., "Shape Memory Alloy: Modeling and Numerical Simulations of the Finite-Strain Superelastic Behavior", Computer Methods in Applied Mechanics and. Engineering, 143(1997); pp.175-194.

(7) 都井裕, 計算固体力学入門（材料と構造のモデリングとシミュレーション), (2008), pp.56-83, コロナ社.

(8) Tobushi, H., Iwanaga, N., Tanaka, K., Hori, T. and Sawada, T., "Deformation Behavior of Ni-Ti Shape Memory Alloy Subjected to Variable Stress and Temperature”, Continuum Mechanics and Thermodynamics, 3 (1991), pp.79-93. 